\title{
CRONOLOGÍA Y APUNTES SOBRE LAS EDICIONES POÉTICAS DE
} ALFONSO SASTRE

\author{
PABLO CARRIEDO CASTRO \\ Investigador. León
}

\section{Resumen}

La de poeta es una de las facetas más desconocidas de Alfonso Sastre. A la sombra de su obra teatral y ensayística (donde ha cosechado su mayor éxito y su mayor reconocimiento público), el escritor acumuló a lo largo de los años también un nutrido conjunto de textos poéticos que fue publicando de manera desigual o discontinua desde 1976 hasta 1994, o que permanecieron inéditos. Con motivo de la publicación de su Obra lírica y doméstica. Poemas completos en el año 2004, el presente artículo quiere contribuir a su conocimiento y difusión aportando una cronología completa de sus poemas y unos breves apuntes desde los que valorar su trayectoria.

\begin{abstract}
That of poet is one of the most unknown facets of Alfonso Sastre. In the shade of his works on the drama and the essay (in which has harvested his major success and public recognition), throughout the years, the writer also accumulated one abundant set of poetical texts, that he was editing in an unequal or discontinuous forms from 1976 to 1994, or remained unpublished. On the occasion of his Obra lírica y doméstica. Poemas completos in 2004, the present article wishes to contribute to its knowledge and diffusion giving a complete chronology of his poems and a few brief notes from which to value his development.
\end{abstract}




\section{Introducción}

$\Psi^{n}$ el año 2004, la editorial guipuzkoana Hiru Argitaletxea $\mathcal{L}$ (Hondarribia) editaba la poesía reunida de Alfonso Sastre. El ejemplar, titulado Obra lírica y doméstica. Poemas completos, constituía un verdadero regalo, largamente esperado, para los seguidores del polifacético escritor matritense. La obra poética de Alfonso Sastre (el más grande dramaturgo vivo de la lengua castellana -Escuadra hacia la muerte, 1952; La mordaza, 1954; Ana Kleiber, 1955; La taberna fantástica, 1966; Ahola no es de leíl, 1975; El viaje infinito de Sancho Panza, 1984; Los últimos días de Emmanuel Kant, 1985-; autor de ensayos de referencia imprescindibles para comprender con exactitud y rigor la evolución de la literatura española contemporánea -Anatomía del realismo, 1965; Crítica de la imaginación, 1970; La revolución y la crítica de la cultura, 1970; Los intelectuales y la utopía, 1995-; cultivador de la novela y del relato testimonial -Historias de California, 1994-; filósofo, teórico del arte y del lenguaje -Lumpen, marginación y jerigonza, 1980, verdadero prodigio de la sociolingüística-; guionista de cine y televisión, cronista, articulista y hasta artista plástico) se encontraba, hasta 2004, en un estado fragmentario y disperso, siendo la parte de su obra de más difícil acceso: editoriales desaparecidas, existencias agotadas, falta de reediciones, distribución deficiente o el desconocimiento, sin más, complicaban la búsqueda de sus ejemplares por librerías de ocasión, ferias del libro antiguo y bibliotecas -no tan bien surtidas-, convirtiéndose en una empresa verdaderamente molesta y, en ocasiones, realmente frustrante. Obra lírica y doméstica. Poemas completos vino a restituir ese vacío con una recopilación de envergadura, tanto histórica como humana, del conjunto de sus libros poéticos publicados entre 1976 y 1994 (a excepción de El evangelio de Drácula, hecho público en 1976 en la 
revista catalana Camp de l'Arpa y reeditado en 1997 por la propia editorial Hiru), a los que se añadía, además, un volumen inédito que veía la luz por primera vez bajo el título de Residuos Urbanos. Una vez reunidos todos los ejemplares se daba el primer paso en firme para la recuperación de Alfonso Sastre como autor lírico.

\section{Las ediciones poéticas de Alfonso Sastre]}

Acercándose analíticamente a la producción poética de Alfonso Sastre desde su obra completa, destaca, entre todos, un aspecto: la accidentada y compleja organización editorial que presentan sus volúmenes en el tiempo. En primer término, los textos de Alfonso Sastre no obedecen nunca a un orden cronológico. Por ejemplo, sus dos primeros poemas de los que tengamos noticia, titulados "Otoño" y "Perdida infancia", escritos ambos en 1942 —cuando el poeta cuenta dieciséis años de edad-, no verán la luz hasta treinta y casi sesenta años después (1978 y 2004,) respectivamente. Se trata de una constante. Sus libros van apareciendo en el panorama literario de una manera dispersa, irregular y alterna; a menudo, las composiciones más antiguas son las que tardan más en hacerse públicas; $\mathrm{y}$, con frecuencia, textos de diferentes épocas y periodos se agrupan bajo un mismo título en función de otras claves compositivas, complicando notablemente la extracción de una poética.

En ese sentido, una ventaja sobresaliente a la hora de trazar el historial de su poesía consiste en la costumbre del autor de datar sus creaciones; los poemas suelen ir acompañados de detalles cronológicos referentes al momento y el contexto exacto de su composición: lugar, condiciones en que fueron concebidos y fecha (año, mes y hasta día) de la escritura. Así, sabemos que desde los años cuarenta, Alfonso Sastre no deja de cultivar en ningún 
momento el género lírico. Siempre a la sombra de su monumental obra teatral y ensayística, el autor va reuniendo un volumen de inéditos mucho más que considerable y de verdadera altura, pero que no se decide a publicar en forma de libro hasta el año 1976. Hablo, en concreto, de sus ediciones poéticas, ya que, sí existen publicaciones previas de textos y colecciones breves en algunas revistas de los años cincuenta y sesenta. Su primer texto lírico hecho público, titulado “Tragedia en tres actos", data del año 1951 en la publicación Madrid. Igualmente, durante 1953, varios de los poemas que integran su cuaderno “Tarde en la taberna” ven la luz en la revista Poesía española. Ya en el año 1957, salen sus “Tres poemas alrededor del teatro" y en 1963 lo harán varios sonetos. Se trata de piezas que se complementan con otras publicaciones (composiciones, en rigor, de agitación y propaganda, algunas de ellas firmadas con sobrenombre) sacadas a la luz en boletines o pasquines clandestinos elaborados con multicopista y de acceso muy complicado. En 1968, publica su extenso poema "El español al alcance de todos" (que daría nombre después a uno de sus libros), reeditado en 1975 por la revista catalana Camp de l'Arpa, plataforma donde saldrán también a la luz, finalmente, varios de sus "poemas celulares". 1 Se trata, en general, de publicaciones muy ocasionales que constituyen apenas una punta del verdadero iceberg que conformaba su abundante producción poética - tal y como él la denomina- "secreta".

Así pues, como se ha dicho, Alfonso Sastre no se decide a publicar nunca un libro de poesía hasta el año 1976. Para entonces, es ya un autor plenamente consolidado y reconocido, con una idea clara y bien definida de la literatura de su tiempo, de su propio arte y de su lenguaje; de lo que quiere transmitir, para qué y cómo hacerlo. Se estrena en el género con La Balada de Carabanchel y otros poemas celulares, un poemario apenas recién escrito, compuesto entre los meses

\footnotetext{
${ }^{1}$ César de Vicente Hernando, “¿Has entendido ya que YO eres TÚ también? Notas a la poesía de Alfonso Sastre" en Anthropos 126 (1991), p.48.
} 
de octubre de 1974 y enero de 1975 durante su reclusión de un año en la cárcel de Carabanchel. Editado por la mítica editorial Ruedo Ibérico de París, verdadero referente de la literatura anti-franquista, La Balada de Carabanchel es un volumen maduro y contenido, de una gran contundencia formal; cuenta con un argumento bien estructurado, situado técnicamente en las proximidades estilísticas del drama y elaborado bajo una influencia muy nítida de las técnicas teatrales de composición. En varios de sus escritos teóricos (El drama y sus lenguajes, I y II. Hiru. Hondarribia. 2000) el autor ha hablado de las relaciones estrechas que mantienen en su ideario los géneros dramático y lírico, estableciendo algunas similitudes y diferencias entre ellos. En primer lugar hay que contar con que Sastre entiende la poesía en el sentido más amplio del concepto (en una tradición racionalista que desciende de Aristóteles); es decir, tiene una idea de la poesía como arte central a toda manifestación creativa, definiéndola, en sí misma y literalmente, como el "lenguaje de la imaginación". Desde esos presupuestos, podemos decir que toda su producción literaria obedece y responde a unas pautas generales o rasgos constitutivos situados dentro del ámbito de "lo poético": ritmo, musicalidad, eufonía, retórica y gramática, que pueden considerarse comunes a toda su producción literaria: “Yo no asocio —explica- a la noción de poesía ningún misterio particular [...] ni siquiera la pienso como algo esencialmente asociado a los versos, según la noción corriente [...] en que los poetas serían, sencillamente, unos escritores versificantes, sino que entiendo por poesía lo que en otros términos peores se ha llamado muchas veces literatura de creación, para distinguirla de la prosa científica y de la prosa filosófica". ${ }^{2}$

Al analizar La Balada de Carabanchel y otros poemas celulares desde ese ángulo, encontramos que las diferencias con respecto a sus obras teatrales

\footnotetext{
2 Alfonso Sastre, El drama y sus lenguajes (I) Hiru, Hondarribia, 2000, p. 419. 
publicadas hasta entonces se reducen a verdaderos mínimos, centradas únicamente en la formalización superficial del discurso, en este caso, en el uso del verso frente a todos los otros recursos de composición que ofrece el ejercicio literario. Según apunta César de Vicente Hernando, los procedimientos de escritura que desprende la poesía de Alfonso Sastre escrita en este periodo se apoyan en los hallazgos de Bertolt Brecht en el ámbito de la poesía narrativa, con un referente muy nítido en la recuperación de "la balada", 3 modelo que señala inequívocamente la génesis popular de su creación en el radio de la literatura revolucionaria que él mismo promueve activamente desde comienzos de los años sesenta. De forma amplia, los textos de La Balada de Carabanchel están dominados por medio de una implacable economía lingüística: una escritura realista muy depurada, un lenguaje seco y duro, plenamente permeable a lo actual, pero de precisión y sutil, de verso libre y ritmo interno. Predomina un tono narrativo e histórico, basado en su propia experiencia de la realidad, y decantado sobre un argumento causal (es decir, orgánico y circular), que cohesiona de forma estrecha todos los componentes estructurales del contenido, inequívocamente, puestos al servicio del compromiso social y de la denuncia. El libro muestra al lector de manera muy cruda lo que era la vida en las cárceles franquistas para un preso político, sus pormenores y dificultades más cotidianas, donde cuaja ya una intensa fascinación por el mundo de la marginalidad social, el llamado sub-proletariado y el lumpen, por la gran expresividad plástica de su lenguaje, que será fecunda en algunas de sus obras

\footnotetext{
3 “Per a Brecht, que cerca l'expressió realista per damunt de tot, cal intentar de resucitar una certa poesia narrativa, que en ell pren la forma de la balada. Tot al llarg de la vida de Brecht, trobem la influència de la balada, la Moritat (moralitat) tal com era cantada pels musics ambulants a les fires del camp; relats sinistres d'assassinats i de execucions, compots en un estil emfàtic, en el qual la sensibleria ploranera competia amb l'horror mes ingenu. Brecht va adoptar aquest estil vulgar com a protesta contra la precocupació de distinció i de respectabilitat cara a la societat burguesa que avorria". José María Castellet, Poesia, realisme, història, Barcelona, Edicions 62, 1965, p. 33.
} 
posteriores. ${ }^{4}$ En general, el ejemplar puede integrarse en el subgénero de la poesía carcelaria (muy abundante en nuestras letras desde los Siglos de Oro y sobre el que existe bibliografía especializada de conjunto) ${ }^{5} \mathrm{y}$, sin duda, echa por tierra la idea de que el franquismo fue un régimen liberal durante sus estertores. Su poema "Nada nuevo", un testimonio crítico de gran dureza sobre la represión en la España del periodo (con su propia detención y la de su esposa Eva Forest como fondo) ilustra este aspecto:

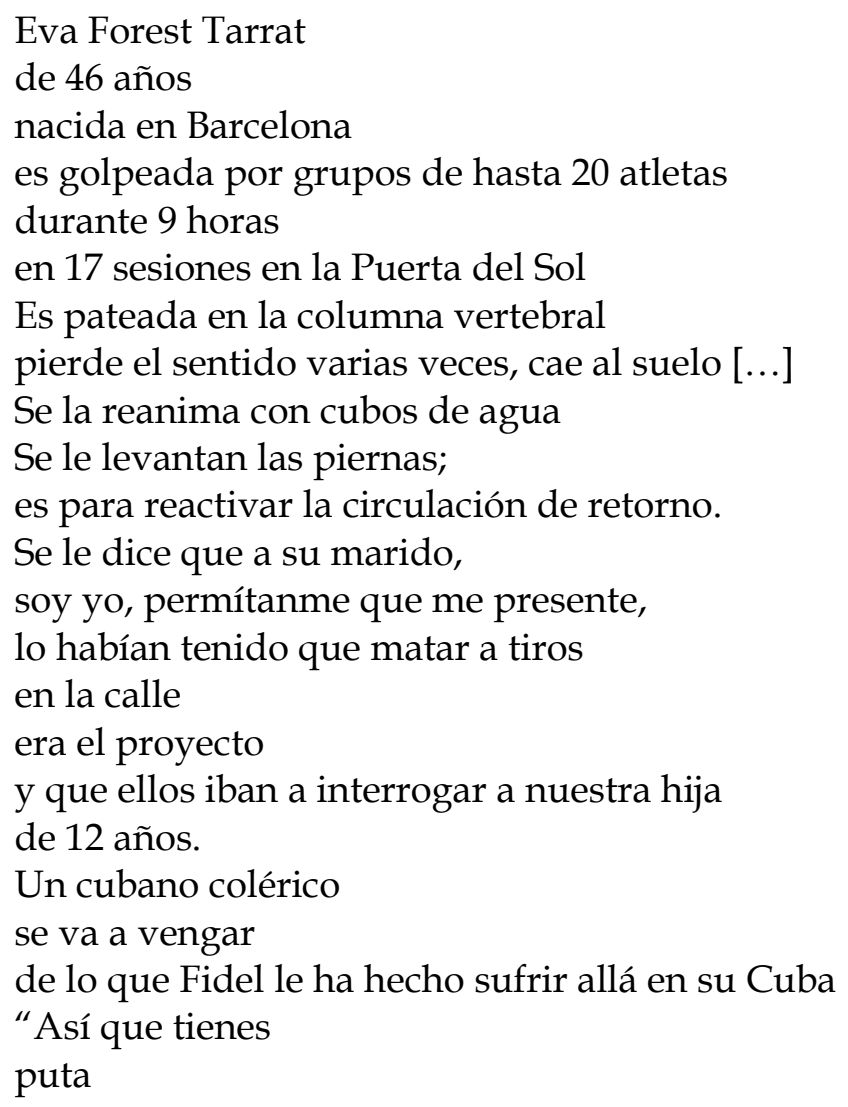

4 "El que esto escribe ha andado siempre entre crudas basuras y estos angélicos personajes; ha convivido con el lumpen y hasta ha hecho, aunque haya sido por motivos políticos, sus pocas estancias en el estaribel, con el oído siempre muy atento a las hablas de las más variadas gentes tan delincuentes como uno mismo. [...] A todas ellas dedico, pues, esta escritura que se quisiera alegre como estas gentes lo son -alegres y libertarias avant la page son estos compañeros con quienes he pasado momentos entre los mejores de mi vida- y han de continuar siéndolo seguramente: alegres y libertarios, digo". Alfonso Sastre, Lumpen, marginación y jerigonza, Madrid, Legasa, 1980, pp.17-18.

${ }^{5}$ José María Balcells, Poesía castellana de cárcel, Barcelona, Dirosa, 1976. 
un hijo en Cuba

Estudiando para comunista verdad?" [...]

Acude la científica

una tía gorda repintada

Sigan, sigan, va bien del corazón

les dice doctoral $[. .$.

Un eunuco enamorado

babeante

"Me vas a matar", le dice acariciándola

¿Seguimos? No, ya basta

La abogado Lidia Falcón,

enferma hepática,

es golpeada por fuertes puños en el hígado [...]

La señora Carmen Nadal

es golpeada en los oídos;

ahora tiene lesiones, pierde el equilibrio

y es obligada a andar de rodillas.

Es vista por los pasillos de la DGS

tambaleándose.

Antonio Durán Velasco, albañil, presenta un rostro tumefacto,

ahora sufre de la columna vertebral,

tuberculosis

y de hemorragias en los ojos.

No sabemos si queda ciego, él, que tanto miraba

las cosas de este mundo.

Mariluz Fernández,

maestra,

ha desaparecido desde su detención.

Nadie la ha visto desde hace ya tres meses.

Ningún abogado ha tenido acceso a su persona.

Sigue, seguramente,

con su vestidito de verano, ya harapiento,

el que llevaba cuando fue detenida. [...]

y de los militantes vascos qué decirles;

moribundos, han sido interrogados

brutalmente; es costumbre [...]

Quería sólo

desde esta prisión de Madrid con mi Balada escrita a sangre

amargarles un poco el whisky mostrando mi cuchara

Vano intento lo sé váyanse a la mierda.

Pero tú compañero desconocido

que has leído estos versos 
seas quien seas acompáñanos ${ }^{6}$

Sin embargo, La Balada de Carabanchel y otros poemas celulares no constituye solo un testimonio lírico de su tiempo y su propia experiencia, sino que consigue situar su verso en una dimensión humana ejemplar, es decir, logra convertir ese escenario concreto y real, en una muestra paradigmática de la resistencia del hombre ante las adversidades más extremas. Es cierto que el grado de referencialidad al que llega su lenguaje es muy alto, subrayado por la aparición de hechos y personajes históricos perfectamente reconocibles para el lector: Santiago Carrillo, el comisario jefe de la Brigada Social, Lidia Falcón, Eva Forest, el propio Alfonso Sastre, Francisco Franco, Fidel Castro, Ernesto Guevara, Cristo, entre otras tipologías (todas ellas carcelarias), como gitanos, quinquis, navajeros, presos políticos o funcionarios de prisiones y torturadores, que constituyen su paisaje humano esencial. En cualquier caso, no debe perderse de vista que todos esos personajes y elementos están transformados estéticamente y se relacionan entre sí dentro del espacio de una ficción; se trata, en rigor, de un decorado donde se representa un suceso real; en otras palabras, el texto adopta la forma de un drama: "un drama - explica el escritor- es una historia que nos cuentan sus propios protagonistas actuando ante nosotros, a veces apoyados por un narrador que, aunque en el manuscrito figure como el autor, no deja de ser otro personaje, dicho y actuado por un actor". 7 Sastre crea aquí, por tanto, una situación dramática, construye una geografía escénica, coincidente con la de la cárcel de Carabanchel, desplazándose desde la realidad (o la denuncia) hasta su transformación crítica. El lector ejerce ahí un papel clave en y, de hecho, el texto depende muy estrechamente de su participación. En medio de una intensa atmósfera de degradación (el verdadero paisaje del

\footnotetext{
${ }^{6}$ Alfonso Sastre, La Balada de Carabanchel y otros poemas celulares, París, Ruedo Ibérico, 1976 pp. $18-21$.

${ }^{7}$ Alfonso Sastre El drama y sus lenguajes (I) Hiru, Hondarribia, 2000, p. 418.
} 
libro), sometidos a torturas y humillaciones constantes, a la represión y al crimen mismo ("puede ser un tiro por la espalda o cualquier otro método", teme el escritor en el poema “El pequeño testamento"), los personajes presos han de enfrentarse, no tanto a sus carceleros y guardianes (en la dimensión histórica de la obra), como, sobre todo, a su propio aislamiento y a su soledad, a los fantasmas que les asaltan y a sus miedos; se trata de una lucha que enfrenta el delirio y la renuncia contra las convicciones más profundas del individuo (en última instancia, el motivo de la reclusión del preso político) que el encarcelamiento y el terror pretenden doblegar. En esas circunstancias, la causa, el compañerismo, la capacidad de dar y de recibir calor humano y apoyo, conforman los pilares de toda la estructura de valores (valores revolucionarios, marcados ideológicamente) que Sastre quiere transmitir y compartir. Por ejemplo, encerrado en una celda de castigo, apenas un hilo de voz es capaz de sostener en equilibrio al personaje; unas palabras, aun tenues y breves, son capaces de transfigurar el entorno surrealista y delirante en que se encuentra, un escenario que desborda y desespera al personaje al modo calderoniano (donde sueño y realidad llegan confundirse), para dar un significado a su situación, ordenar ese caos confuso y sin sentido que percibe y no comprende, y, así, restituir una lógica y justificar, finalmente, una buena alegoría del compromiso:

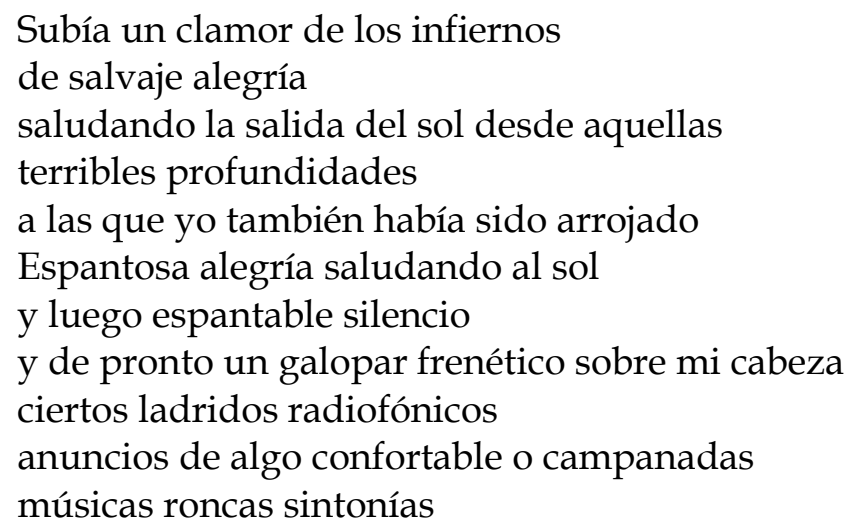




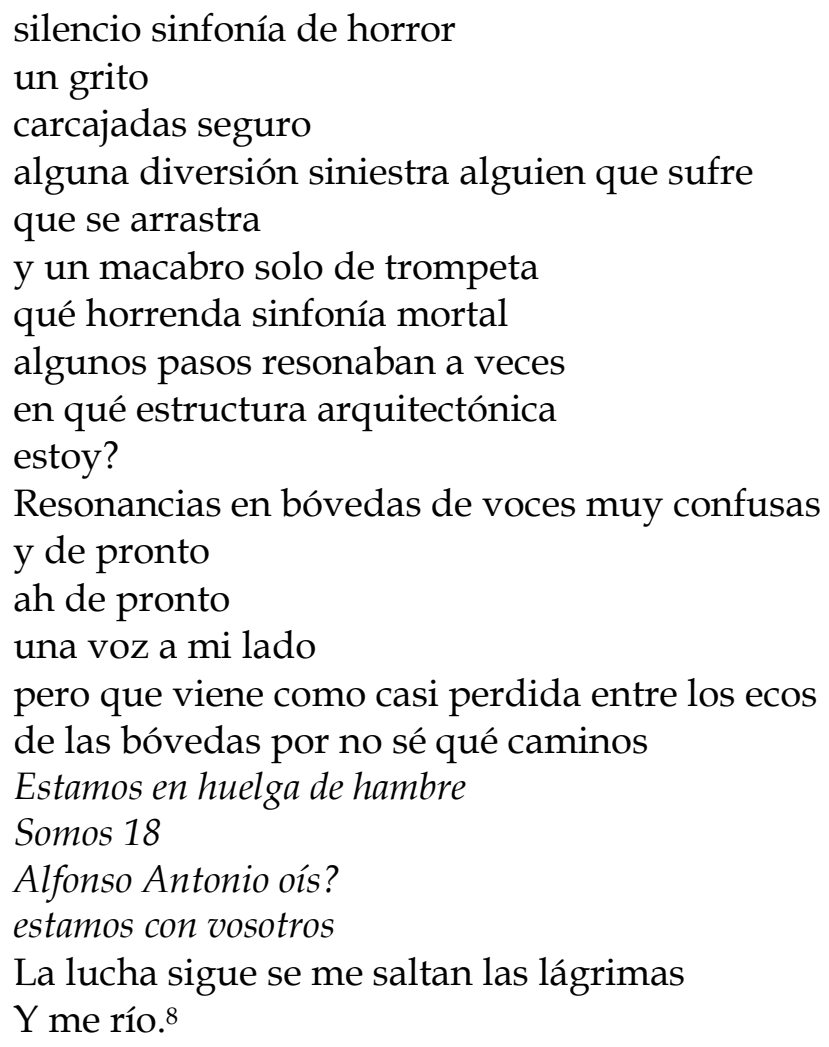

En el mismo 1976, Alfonso Sastre publica el segundo ejemplar lírico de su trayectoria, titulado El evangelio de Drácula, (Camp de l'Arpa. Barcelona). Compuesto en su totalidad en el mes de mayo de 1975, estando todavía en prisión, Alfonso Sastre lo subtitula "Horror y poesía (Un capricho)", indicando en su prefacio que los versos fueron escritos, literalmente, como una "evasión de la cárcel, ¡fuga, ay, imaginaria!", con lo que el propio autor establece ya el margen interpretativo de su libro dentro de los presupuestos del arte simbolista; en última instancia, una manera de "escapar" del aburrimiento al que estaba condenado en prisión. El ángulo simbólico abre paso a un ambiente lúgubre y romántico, muy cercano al estilo de las Leyendas de Bécquer o al del Estudiante de Salamanca de Espronceda. Sastre sitúa la acción en los Cárpatos rumanos, en un periodo histórico indefinido (aproximadamente el siglo XIX) y

${ }^{8}$ Alfonso Sastre, La Balada de Carabanchel y otros poemas celulares, op.cit., p. 40 
durante una noche de tormenta, cuando un grupo de hombres y mujeres, refugiados en casa de un misterioso desconocido, se reúnen en torno al fuego para escuchar de su boca la historia de Drácula, "un demonio triste" que se rebeló contra el dios de los cristianos. El texto conjuga varios aspectos interesantes que remiten a su propia obsesión por el tema religioso, y se desprende, nuevamente, una fuerte impronta teatral, sobre todo, en la construcción de los paisajes y los espacios al modo de una secuencia de escenas. Frente a La Balada de Carabanchel, que ofrecía un lenguaje más actual y contemporáneo, Alfonso Sastre hace gala aquí de un extraordinario refinamiento lingüístico. Se trata de un lenguaje inequívocamente culto, enriquecido con frecuentes encabalgamientos $y$ pausas, cuajado de construcciones hiperbáticas y arcaizantes; un léxico especializado, fino y evocador, que acentúa la dimensión plástica del verso, girando en torno a un único protagonista que ejerce de personaje de la trama y, a la vez, de narrador sobre el que el autor se proyecta.

En algún momento se ha querido ver el ejemplar como un testimonio cifrado de crítica social (en la idea de Sastre como escritor hiper-politizado, que tanto ha combatido); pero, aunque es cierto que la estructura simbólica que ordena las composiciones abre muchas posibilidades interpretativas, debe ser considerado, en rigor, un homenaje a la literatura de terror, muy frecuentada y admirada por el dramaturgo. En todo caso, sea cual sea la dirección que quiera darse a la lectura, la historia de El evangelio de Drácula alcanza también un estadio netamente representativo $\mathrm{y}$, en este sentido, es un texto claramente ambiguo. ${ }^{9}$ Partiendo de que todo poema implica, en sí mismo, una reflexión

\footnotetext{
9 “La ambigüedad a mí me ha perseguido siempre. Recuerdo un artículo de Haro Tecglen en el que decía que todo lo que yo escribía era tan ambiguo que no se entendía nada. Decía Haro Tecglen: «Quiere hacer una obra de elogio a la revolución y hace una obra anticomunista: El pan de todos. Quiere hacer una obra antimilitarista y lo que sale es un elogio de la disciplina militar: Escuadra hacia la muerte». De La mordaza decía que era «un ataque a la resistencia francesa».
} 
sobre el significado y la trascendencia de la propia escritura y leyendo detenidamente el texto, pueden apreciarse también fuertes inflexiones metapoéticas, tal vez, el verdadero y más relevante contenido del libro. El hecho de que Sastre nos sitúe ante un "evangelio" en el que la palabra (la palabra escrita) resulta un elemento central, y hasta sagrado, en la ordenación y la difusión de unas ideas, puede sostener también una revisión dialéctica de la tradición poética misma y, a través suyo, de la moral que describe. Así en el poema "Continuación del novísimo testamento", donde el escritor explica:

El Evangelio infame de Drácula ordenaba matar y fornicar con artes siempre nuevas; y codiciar los bienes ajenos y robarlos formaba parte esencial de su filosofía; ya la mujer del prójimo era un concepto extraño en todas las comarcas pisadas por sus huestes. ¿Que todo ciudadano llame a su hermano: racca!10 Y si alguien tu mejilla golpease, tú, raudo, machaca su cabeza, atraviesa su cuerpo, ríete de su mueca, incendia su habitáculo y que perezca toda su familia en las llamas. Todo hombre es enemigo, toda piedad locura, todo socorro un crimen, todo crimen la gloria. Oh bienaventurados sean los orgullosos, los que ríen mirando todo el dolor del mundo, los hombres indomables y bravos como hienas, los que se sienten ávidos de nuevas injusticias, los crueles, los sucios de corazón y aquellos que guerrean por un sueldo, ajenos a ideales, e ignoran qué se juega en la batalla.

Son bienaventurados aquellos que persiguen y los que vituperan y calumnian y hunden a su prójimo en fango y celebran su muerte con risas y canciones y desafueros óptimos. Vosotros, jasesinos!, sois la sal de la tierra.

Venía a decir que en todas mis obras se podía ver lo contrario de lo que yo pretendía hacer [...] obra por obra, iba diciendo que los efectos de mis obras son siempre los opuestos a los pretendidos. En cierto modo, algo de eso a veces ocurría". Francisco Caudet, Crónica de una marginación, Madrid, Ediciones de la Torre, 1986, p. 39.

${ }^{10}$ Sustantivo de lengua rumana: "el que tiene mala sangre". 
Vosotros sois, ¡canallas!, la luz de nuestro mundo. ${ }^{11}$

Apenas dos años después de publicar ambos libros, en el año 1978, Alfonso Sastre concibe y publica una recopilación de sus poemas más antiguos, con piezas que oscilan entre 1942 y 1968, reunidos en El español al alcance de todos (Sensemayá, Madrid. 1978). El libro, preparado a modo de antología, está compuesto en su gran mayoría por textos y colecciones inéditas que ven la luz entonces por primera vez. De este modo, aunque los ocho cuadernos que integran la selección son, cronológicamente, muy desiguales (un aspecto que dispersa y que fracciona deliberadamente la unidad de sentido de los textos), El español al alcance de todos ofrece como novedad importante una panorámica de la evolución poética de Alfonso Sastre, lo que equivale a una revisión general de su estética planteada en términos líricos. En ese ángulo, El español al alcance de todos resulta revelador. Cuando a la altura de 1978, se comenzaba a hablar de una "Literatura del consenso", a-problemática y des-historizada, un arte evasivo y lúdico que neutralizara al realismo y sus autores de referencia (es decir, que amortiguara la gran densidad ideológica que había alcanzado la literatura española del momento de cara a materializar culturalmente la transición hacia la democracia), los textos de Alfonso Sastre se intensifican por contraste. ${ }^{12}$ Mientras muchos autores trataban de contrarrestar sus creaciones

\footnotetext{
11 Alfonso Sastre, El evangelio de Drácula, Hiru, Hondarribia, 1997, p. 53.

12 "En aquellos años de la transición [...] la reforma sustituyó a la ruptura, no sobre la base de una concordia que depurase responsabilidades y buscase instaurar un cierto perdón, sino sobre el olvido puro y simple de un pasado que parecía no haber existido jamás [...] La despolitización, y consiguiente deshistorización del presente, fue sistemática, y eso, aunque sea en escala diferente, también se dio en la literatura en general y en la poesía en particular. En términos incluso de política cultural, el Partido Socialista, durante los años de su mandato, siempre favoreció, en la medida de sus posibilidades (que eran muchas) aquellas propuestas que no problematizaran nada, como si mencionar juntos escritura y política fuera mentar la bicha. Si uno estudia con detenimiento qué se apoyó y cómo entre 1982 y 1996, se descubriría una nada sospechosa (porque se hizo a la luz del día) continuidad entre esos años y los que siguieron a su salida del poder. Es triste reconocerlo, pero no toda la responsabilidad de lo que nos sucede pertenece al presente". Jenaro Talens, "Contrapoéticas del realismo" (pp.147-149) en
} 
comprometidas de apenas diez años atrás con la publicación y la difusión de obras nuevas acordes al (democrático) momento, -en otras palabras, a la moda-, intentando, en muchos casos, incluso ocultar su pasado de escritores engageé, el dramaturgo madrileño proyecta una panorámica de sus textos cuyo eje se sitúa en el año 1960, cuando el compromiso llega, sin duda, a uno de sus grados más altos en España. Así lo explica en el prólogo a su selección con las siguientes palabras: “La idea de reunir algunos poemas míos y publicarlos en un determinado marco es de 1960: de ahí esa fecha -la misma al principio que al final: agosto de aquel año-, que sirve como «bolsa» de los poemas, la mayor parte anteriores o posteriores a 1960".13

Aunque las fechas de los poemas se superponen a menudo entre sí, la arquitectura general del libro muestra con nitidez cómo el autor se desenvuelve desde las actitudes post-simbolistas más clásicas hasta una percepción realista del mundo que lo rodea; se aprecia una intensificación, lenta pero progresiva, de la importancia de lo ético y, sobre todo, de lo ideológico, paralela al descenso del matiz religioso de su ideario (muy nítido en sus primeras creaciones) y que, desde los años cincuenta, va definiendo y modulando al escritor esencialmente social y comprometido que será ya siempre. Por ejemplo, los cuadernos "Las baladas ingenuas" y "Tarde en la taberna" que abren el ejemplar, muestran a un Sastre muy juvenil, atravesado por las influencias de Rubén Darío, del Antonio Machado modernista y de François Villon (con intensa presencia de la rima); dominan sus páginas cuadros intimistas y melancólicos, aunque ya de lenguaje conversacional y directo, carente de artificios y pirotecnias que se justifiquen por sí mismos, iluminando así la vida de un estudiante madrileño de los años cuarenta y cincuenta, inquieto y preocupado —si bien en un ángulo cristiano-

Andrés Sánchez Robayna y Jordi Doce (eds.), Poesía hispánica contemporánea, Madrid, Galaxia Gutemberg, 2005.

${ }^{13}$ Alfonso Sastre, El español al alcance de todos, Madrid, Sensemayá Chororó, 1978. p. 7. 
por toda la injusticia que lo rodea. El poema que cierra la serie, fechado en 1948, ilustra este aspecto:

Acabo en marzo esta primera entrega de mis poemas dedicados a las gentes humildes.

Os ofrezco esta entrega para casos sencillos,

Para casos de amor, ausencia o lluvia.

Procuro que el breviario de mis días

esté sencillamente escrito

para que aquellos que no saben de letras

hallen algún consuelo en su lectura.

Que los pobres que lo hayan leído me cuenten entre ellos

pues soy pobre en amor y grande en desventura

aunque como estudiante procuro divertirme.

Acabo, pues, este cuaderno pero os prometo continuar alguna vez.

Solo me queda por ahora

Desearos la paz. Dios os bendiga

a todos para que aún celebréis doscientas primaveras.

Y que nos reencontremos pronto. Amén. ${ }^{14}$

Una revisión sucinta de las distintas poéticas por las que atraviesa la producción española de la posguerra, revelará la sintonía general de la trayectoria de Alfonso Sastre con sus líneas maestras esenciales. Desde la actitud existencial y sus crisis más propias, Sastre se desliza, primero, hacia posiciones inconformistas que comienzan a reflejar y, en consecuencia, a criticar la realidad material y objetiva que los rodea; después, dentro ya de los parámetros de la conocida como poesía social, en plena década del cincuenta, ${ }^{15}$ evoluciona desde el radio comprometido más amplio, hacia actitudes netamente ideológicas en un intento consciente y bien programado de adaptar

\footnotetext{
${ }^{14}$ Alfonso Sastre, "Final de un cuaderno" en El español al alcance de todos, op. cit., p. 27.

15 "La poesía social no es una moda, sino una necesidad expresiva de quienes ponen por encima de todo otro valor el de la dignidad humana y hacen suyo el verso clásico «no he de callar por más que con el dedo», en la convicción de que nada debe quedar al margen de la lucha en defensa de una igualdad y una justicia que aseguren los medios de vida fundamentales para todos, porque ya se ha dicho que la virtud empieza con el bienestar. No es baladí que el pueblo valore y puntualice, en su famosa frase: «pobres pero honrados». Y ya Cervantes añadía: «si es que puede ser honrado el pobre»". Leopoldo de Luís, Poesía social, Gijón, Júcar, [1965] 1981, p. 47.
} 
los presupuestos del arte socialista al arte español de los años sesenta. La dinámica de su poesía corre, por tanto, en paralelo a su evolución teatral (desde el Teatro de Agitación Social, T.A.S. de 1950, al Grupo de Teatro realista, G.T.R. de 1960) y, en este sentido, se registran múltiples filtraciones de temas y técnicas dramáticas utilizadas también en su obra lírica, como sucede, por ejemplo, en el cuaderno "Drama sin apuntador", una variación lírica sobre algunos aspectos del universo teatral y su problemática.

Como tendencia general, a medida que avanza el libro, los cuadernos tienden a desligarse de la "actitud poética" tradicional para ganar, sin embargo, en libertad plástica y expresiva, en ocasiones, fragmentándose en una línea experimental o de vanguardia (como en su poema "Censura": "Termina mi ataúd, carpintero, / y luego / métete dentro. Verás como te entierro"); y, en otras -las más de ellas-, desarrollando texturas narrativas, en las que, de hecho, terminan desenvolviéndose casi todos sus contenidos de referencia (como, por ejemplo, el religioso, cada vez más corrosivo al contacto de la realidad social con la que convive: "Si eres cristiano, amigo, no lo digas a nadie. / Te complicas diciéndolo, / en un negocio turbio. / Niega a Cristo, cristiano: /es ya lo único que puedes hacer por tu maestro"). Desde las páginas de El español al alcance de todos, el lector tiene ocasión de observar un desplazamiento estético y humano ejemplar desde la ingenuidad y la impostura lírica hasta el compromiso a través de temas como la Guerra Civil y las guerras en general, el hambre, la explotación obrera, el racismo o la violencia, cuya aparición se hace progresivamente más intensa hasta culminar en sus textos más modernos (de 1965 en adelante). Es el caso concreto de cuadernos como "Arrojado en el mundo" o "Por encima de todo", al que pertenece el poema, "Yo", donde explica su evolución en los siguientes términos:

Yo tenía la mejor voluntad, señores míos, distinguidos 


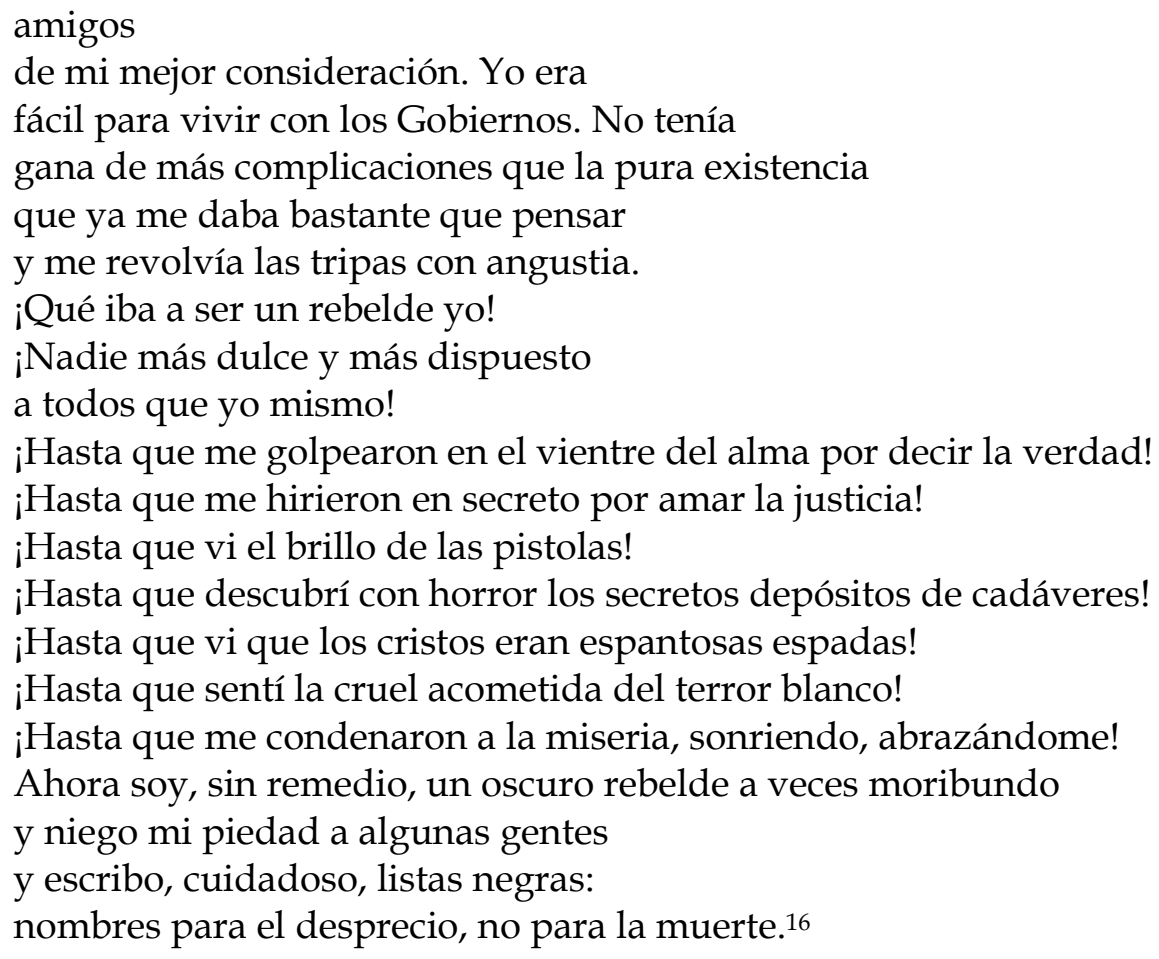

El español al alcance de todos (recordemos que se publica en 1978) descubre al lector además una faceta de Alfonso Sastre, hasta entonces, desconocida en su poesía: el gusto del poeta por el ritmo y la forma clásica. Esa conexión abre numerosas perspectivas de investigación tanto en lo referente a su obra dramática (lecturas del teatro versificado clásico, sus influencias y la adaptación peculiar de sus elementos al universo ideológico y vital del autor, por ejemplo) como propiamente poética. Alfonso Sastre se revela como un excelente cultivador de sus cauces: canciones, romances, tercetos encadenados, décimas, sextillas, seguidillas, redondillas, villancicos, estancias pareadas y, muy en particular, sonetos, un formato que domina a la perfección.

El libro donde mejor puede apreciarse mejor esa inclinación es el siguiente de su trayectoria, titulado T.B.O., ejemplar publicado por la editorial Zero Zyx también en 1978, y compuesto en su práctica totalidad por piezas

\footnotetext{
${ }^{16}$ Alfonso Sastre, "Yo" en El español al alcance de todos, op. cit., p. 136.
} 
clásicas y composiciones menores rimadas, instaladas en la idea del arte popular o proletario. Aunque, en este caso, predominan claramente las composiciones más recientes, escritas en su mayor parte entre 1974 y 1975 (su periodo, poéticamente, más fértil), Sastre rescata algunos poemas de los años cuarenta, cincuenta y sesenta para dar forma a dos de las preocupaciones clave de su mundo literario: la dimensión política de la realidad y su universo familiar: "No son sino versos sencillos nacidos de la vida cotidiana y de la lucha política", explica en el prólogo del libro. Política y vida cotidiana se implican en este ejemplar muy estrechamente y llegan a compartir una misma esencia lírica; contra lo que pudiera parecer a priori, espacios aparentemente tan distantes entre sí como el colegio de su hija Evita, una celda de la cárcel de Carabanchel o el sur del río Yang-Sé, en rigor, integrados por personajes poéticos de perfiles netamente diferenciados y cuyas problemáticas divergen, sin embargo, conviven en T.B.O. en una asombrosa armonía cohesionados por una mirada humanista y, sobre todo, orgánica y relacional del mundo: el poeta es capaz de entusiasmarse lo mismo con un notable en la asignatura de inglés conseguido por su hijo Pablo, que con la toma de Shaigón por el ejército de Ho Chi Minh; lo mismo escribir unos versos para animar a su hija que está triste, que para denunciar la destrucción de unos cuadros de Picasso por los Guerrilleros de Cristo Rey; lo mismo, componer un poema de amor a su compañera o describir una crisis íntima, que elaborar otro dedicado a la falta de libertades en España, dimensión donde ambos universos terminan en muchas ocasiones por coincidir. Se trata, al cabo, de un acercamiento a las inquietudes íntimas del autor, a sus prioridades ideológicas y sentimentales, donde, liberado de los modos canónicos "cultos" en que se relacionan las formas y contenidos poéticos tradicionales, es capaz de desplegar un concepto generoso de lo poético afín a lo 
que él mismo denomina las "hablas naturales". ${ }^{17}$ En este mismo sentido, el libro está cohesionado a través de un lenguaje técnicamente muy ágil y una actitud positiva y vitalista. Existe una marcada influencia de la estética realista barroca, donde se combinan dialécticamente (es decir, por contraste) elementos degradados de aire sainetesco (ya satírico o burlón), con otros considerados tradicionalmente "dignos" o más elevados, de nuevo, en una superposición ambigua de las claves teatrales sobre el verso (construcción de personajes y de máscaras, escenografías, diálogos, efectos se situación, etc.).

Con respecto a sus libros previos, y ampliamente, Sastre se desplaza en T.B.O. del ámbito de la tragedia (el suyo más propio y el que verdaderamente enciende la esencia de su arte), al de la comedia mordaz e irónica. En todo caso, debe tenerse en cuenta que se trata solo de un cambio de enfoque que no afecta en absoluto a la cohesión de conjunto de sus libros ni a las evidencias que señalan. ${ }^{18}$ En general, T.B.O. responde a un intento de conseguir una poesía accesible al pueblo, cotidiana, alejada de la "alta poética", capaz de asociar los elementos propios de un universo realista y "común”, pero, a la vez, elaborado. Para ello, Sastre parte de lo popular como una categoría estética desde la que construir un espacio-tiempo poético (histórico y plenamente identificable) y estructurar un lenguaje que lo formule, según propone en el fragmento de

\footnotetext{
17 "Esas hablas naturales se producen en su propio ritmo interior, no asimilable a las bellezas posibles, literarias, de la prosa rítmica de algunos escritores, rico de léxico y complejos de formas sintácticas: esas prosas «asiáticas» cuyo barroquismo las aleja de las bellezas despojadas (dépouillées) que las diferencia y aleja de las prosas que podrían llamarse -creo que ya se han llamado así- «áticas»: prosas sencillas, equilibradas con sus contenidos ideológicos y/o narrativos" Alfonso Sastre, El drama y sus lenguajes (I), op. cit., p. 448.

18 "[Lo] que se puede tomar por lo cómico, también se puede tomar por lo trágico, y aquí viene lo de que depende de nuestro talante y de nuestro estilo en cuanto que observadores de las cosas que pasan en nosotros y a nuestro alrededor. Es la misma realidad, que se puede tomar y expresar de una manera o de otra, y de ambas maneras [...] insistimos en que son hechos que se producen en la misma y ante la misma realidad dado que, efectivamente, no hay una realidad trágica y una realidad cómica". Alfonso Sastre, Ensayo general sobre lo cómico, Hiru, 2002, pp. 150151.
} 
manifiesto (inédito y fechado en 1972) que precede al libro: “¡...Por una poesía realista y popular...! ¡...Por una poesía de barrio; que empiece en el barrio...! ¿Quién da la voz? ¿Quién da la vez?”. Los ejemplos son constantes a lo largo de los tres cuadernos que componen el libro: “Andar por casa”, “Te veo Vietnam” (compuesto por versos pareados de gran dinamismo a modo de aleluyas) y un muy interesante "Cuadernillo de anónimos", que abre el libro, en la mejor tradición oral castellana: poemas o colecciones (a veces firmados con seudónimo) aparecidos en publicaciones clandestinas o de intención crítica entre los que merece destacarse su colección "Catorce sonetos Einauditos, llamados así porque la editorial italiana Einaudi publicó en 1962 un cancionero antifascista español y la que se armó con este motivo", donde se encuentran poemas como "El pueblo renuncia a su salvación eterna":

\footnotetext{
Cuánta blasfemia, oh pueblo empecinado.

Escarneciendo imágenes y ritos, en términos blasfemos e inauditos te defecas en todo lo sagrado.

En lugar de mostrarte resignado y bendecir la mano que te azota y ofrecer tu mejilla patriota al golpe del verdugo enamorado,

tú revuelves zafio y manchas y todo con sucia boca y taco de taberna, untando el aire con tu baba y lodo.

No hay en ti una palabra dulce y tierna $\mathrm{y}$ te niegas tozudo de este modo a disfrutar después la vida eterna. ${ }^{19}$
}

\footnotetext{
${ }^{19}$ Alfonso Sastre, "El pueblo renuncia a su salvación”, T.B.O., Madrid, Zero Zyx, 1978, p. 13. 
El texto "Mujer correctamente fusilada", ilustra igualmente el estilo, aparentemente desenfadado, y burlesco que desprende el volumen en su conjunto:
Seguro que fue roja la cuitada madre de este poeta puro y fino que no blasfema del furor divino mas recuerda a su madre fusilada.
Estudiados la causa y expediente, se encuentra que ella fue simpatizante de su marido, un líder importante al cual ella apoyó constantemente. $\mathrm{Y}$ así, fue condenada su asistencia a aquella rebelión de rojos fieros, por imparciales jueces sin violencia,
hijos de asesinados caballeros.
Quién podrá protestar de tal sentencia?
Sólo, claro, los rojos extranjeros. ${ }^{20}$

Es sabido que Alfonso Sastre, por distintos motivos, alcanzó una merecida (y, en su caso, meritoria) fama de autor rebelde y conflictivo. Procesado y encarcelado varias veces por actividades políticas contra el régimen franquista, expedientado por la censura en incontables ocasiones, y hombre crítico y transparente más allá de toda circunstancia, esa actitud, sin embargo, provocó que varias plataformas editoriales y culturales del país le cerraran sus puertas definitivamente. ${ }^{21}$ Un ejemplo lo encontramos en su libro Vida del hombre invisible contada por él mismo, que puede contarse entre sus

\footnotetext{
${ }^{20}$ Alfonso Sastre, "Mujer correctamente fusilada", T.B.O., op. cit. p. 16.

${ }^{21}$ En la nota que precede al libro de entrevistas con Alfonso Sastre, Crónica de una marginación, Francisco Caudet, hace constar los problemas editoriales a los que se enfrentaba entonces el dramaturgo: "He querido combinar -explica- el trabajo académico con el periodístico, hacer un libro original... Y todo ello sabiendo que me iba a encontrar con una fuerte oposición por parte de los editores que, como he podido constatar (algo que ya dábamos por sentado Alfonso y yo) juzgan inoportuno o nada comercial a mi entrevistado". Francisco Caudet, Crónica de una marginación, op.cit., p. 11.
} 
mejores textos. Compuesto en el mes de octubre del año 1980, el manuscrito solo podrá ver la luz catorce años después de ser escrito, editado por la editorial Endymión de Madrid tras haber sido rechazado, previa y reiteradamente, en varias firmas. Desde un punto de vista técnico, Sastre vuelve a situarse con este ejemplar en el filo mismo de varios géneros literarios. Aunque se trata de textos de nítido predominio poético, su contenido (volviendo sobre los acontecimientos que rodearon su detención del año 1974), los aproxima al relato testimonial de clave histórica, proyectándolos también sobre un fondo dramático inequívoco en el que toma forma uno de los personajes que lo definen ya como autor literario: el hombre invisible.

En varios de sus escritos y papeles, el propio Sastre ha reflexionado, con ironía y buena dosis de resignación, sobre el fenómeno de la invisibilidad como una categoría ética e histórica, aplicable al conjunto de su monumental obra literaria. $^{22} \mathrm{Si}$ aceptamos la definición del escritor invisible, según Sastre la propone, como una clase referencial donde [1] la represión política, moral e intelectual [2] la censura y [3] la política de mercado de la industria del libro, actúan como rasgos literarios distintivos, el llamado "caso Alfonso Sastre", puede considerarse paradigmático y extremo en nuestras letras, aunque, desde 1939, abunden en la Literatura Española ese tipo de casos insólitos. La noción de invisibilidad se encuentra en Sastre estrechamente ligada a su activismo y a las consecuencias que se derivaron de él (tanto durante la dictadura como después); en rigor, aquellos hechos conforman uno de los temas más recurrentes de sus textos poéticos, vuelven constantemente a su verso,

22 “Entre mis pocas hazañas, de las que tampoco quiero jactarme demasiado, cuentan, a lo largo de mi ya dilatada vida -estoy cumpliendo sesenta y seis años en los momentos en que escribo estas líneas-, la de haber sido impublicable, irrepresentable, indeseable e invisible. La censura, la policía, y varios editores, directores, actores y empresarios de teatro tienen algo que ver en esto. ¿He de contarlo algún día? No creo que valga la pena, a no ser por lo que mi experiencia pueda tener de signo que expresa una situación general". "Escrito en Euskadi". http://www.sastre-forest.com 
encontrando así el cauce más adecuado de exploración emocional y de expresión entre todos los posibles. Entre las diferencias que separan Vida del hombre invisible contada por él mismo de otros conjuntos textuales que abordan el mismo tema, se encuentra la perspectiva que el tiempo y la distancia han arrojado sobre los acontecimientos, trascendentales en su vida, de 1974. Si La Balada de Carabanchel, por ejemplo, o algunos de los textos incorporados a T.B.O., se situaban en un ángulo sincrónico a su encarcelación, dotándolos de una fuerte impronta de inmediatez y de actualidad con respecto a los sucesos que describen, sabemos que su nuevo libro está compuesto a más de cinco años de su estancia en prisión. El reflejo plástico de esa distancia aporta una mayor carga de reflexión ética de la que carecen sus piezas previas: "Esos momentos [explica en el prólogo al libro] se han presentado en la memoria con arreglo a una lógica - ¿la lógica del inconsciente?- indeterminable, de modo que presentan una diacronía más que nada caótica, ¿o poética? [...] Han sido -prosigue- quince días de ensueño y también de catarsis de unos contenidos que tiritaban (sin saber cómo expresarse) en el alma; y que ahora se han manifestado, por fin, fuera de ella". ${ }^{23}$ Un tono pausado, un ritmo más lento de lo habitual y un lenguaje plenamente abierto a la metáfora, al detalle lírico y a la amplitud dan forma a una secuencia de escenarios en movimiento, a veces, imaginarios, otras veces, reales o históricos, entre los que "hombre invisible" se desenvuelve (frente a otros de sus poemas) en equilibrio. El personaje demuestra una extraordinaria capacidad de penetración dialéctica en la realidad, descubre su ambigüedad y su carácter equívoco, a menudo, alejando deliberadamente al lector de la denuncia (referencial o lingüísticamente marcada) para acercarlo a una vía de alternativa conocimiento de su entorno, a las contradicciones que encierra, un ángulo en el que los textos alcanzan su

\footnotetext{
${ }^{23}$ Alfonso Sastre, Vida del hombre invisible contada por él mismo, Madrid, Endimión, 1980, p. 9.
} 
verdadera plenitud. En la pieza "Niña de comisario", el hombre invisible, recién detenido por la policía franquista (trasunto de los tristemente famosos calabozos de Puerta del Sol), explica:

\author{
Enfurecióse el comisario \\ al leer mi declaración sin malos tratos obtenida \\ y rompióla colérico delante de mis ojos muy turbios de tristeza \\ y arrojó sin piedad al torturado suelo los papelillos rotos \\ los confetti de angustia de opaca resistencia de cadáver \\ pisoteólos creo \\ y ordenó al funcionario hepático y vidrioso \\ empezar otra vez \\ de modo más enérgico \\ a interrogarme sobre comunistas habidos \\ en ilegal reunión \\ cierto día de invierno \\ Yo me sentí cazado como un pintado pajarillo \\ en aquella polvorienta oficina no más siniestras que otras tantas \\ donde uno a lo más bostezaría \\ y me dispuse a ser un tanto heroico \\ dentro de lo posible \\ cuando una dulce niña penetró en la estancia \\ y besó al señor comisario en la mejilla \\ pues iba a misa y vi que era domingo \\ en el velito y en el devocionario de aquella pequeñuela \\ y vi con estos ojos que el rostro antes colérico ahora resplandecía \\ y un halo de bondad nimbó su cráneo \\ y oyéronse palabras familiares dile a mamá bonita \\ que no podré almorzar en casa tengo tanto trabajo esta mañana \\ y lo decía sin rencor y sin mirarme de malas formas cumpliendo digo yo \\ sin duda sus deberes \\ y ahora lo vi más viejo \\ y así como encorvado bajo el peso \\ de responsabilidades ciudadanas y lo miré piadosamente \\ La luz de la oficina se hizo más oscura \\ cuando la niña se marchó ${ }^{24}$
}

\footnotetext{
${ }^{24}$ Alfonso Sastre, "Niña de comisario", Vida del hombre invisible contada por él mismo, op.cit., p.14 
Vida del hombre invisible contada por él mismo es la transformación poética de los pasajes reales vividos por Alfonso Sastre entre su procesamiento de 1974 y el año 80. El libro se desenvuelve, por tanto, en una dimensión histórica perfectamente documentable: su propia detención y la de su esposa Eva Forest, su exilio en Burdeos en 1975, la huelga de hambre que protagoniza en 1976 en la catedral de Bayona, su repatriación a España, la legalización del PCE (del que llegó a ser miembro de su Comité Central), la prohibición de entrada en Italia para dictar unas conferencias sobre la dictadura y el problema español, los registros domiciliarios a los que es sometido (un verdadero tópico literario del periodo) o su procesamiento por injurias a las fuerzas armadas de 1978, son acontecimientos que dominan panorámicamente todos los poemas estableciendo un marco histórico. Desde ellos el lector puede acceder a la dimensión íntima del personaje (la complementaria a la histórica), a sus distintos estados emocionales, sus preocupaciones cotidianas y hasta a sueños más puntuales o anecdóticos: pensamientos u ocurrencias, entre trágicas y hasta divertidas, plegadas todas a la situación excepcional en que vive y que limita ambos universos. Sin embargo, la combinación poética de ambas dimensiones a través del hombre invisible (el logro más notorio de este libro), no es ya solo propia del escritor llamado Alfonso Sastre, por más que se haga visible a través de su propia vida; de hecho, ni tan siquiera pertenece a la clase de los escritores perseguidos por sus ideas políticas (muy abundante); sino que es común a una buena parte de la sociedad española que combatió la dictadura franquista, incluso más allá de la muerte del general Franco, desde la clandestinidad y en numerosas áreas de actividad profesional. Se trata, al cabo, de una tipología literaria específica capaz de señalar y de explicar un estadio reciente de la historia de nuestro país en el que pertenecer a la izquierda era verdaderamente arriesgado. Alfonso Sastre plantea el tema en algunos de los textos del libro, 
como en su "Tratado del hombre clandestino", donde, al modo de una clase magistral, explica:

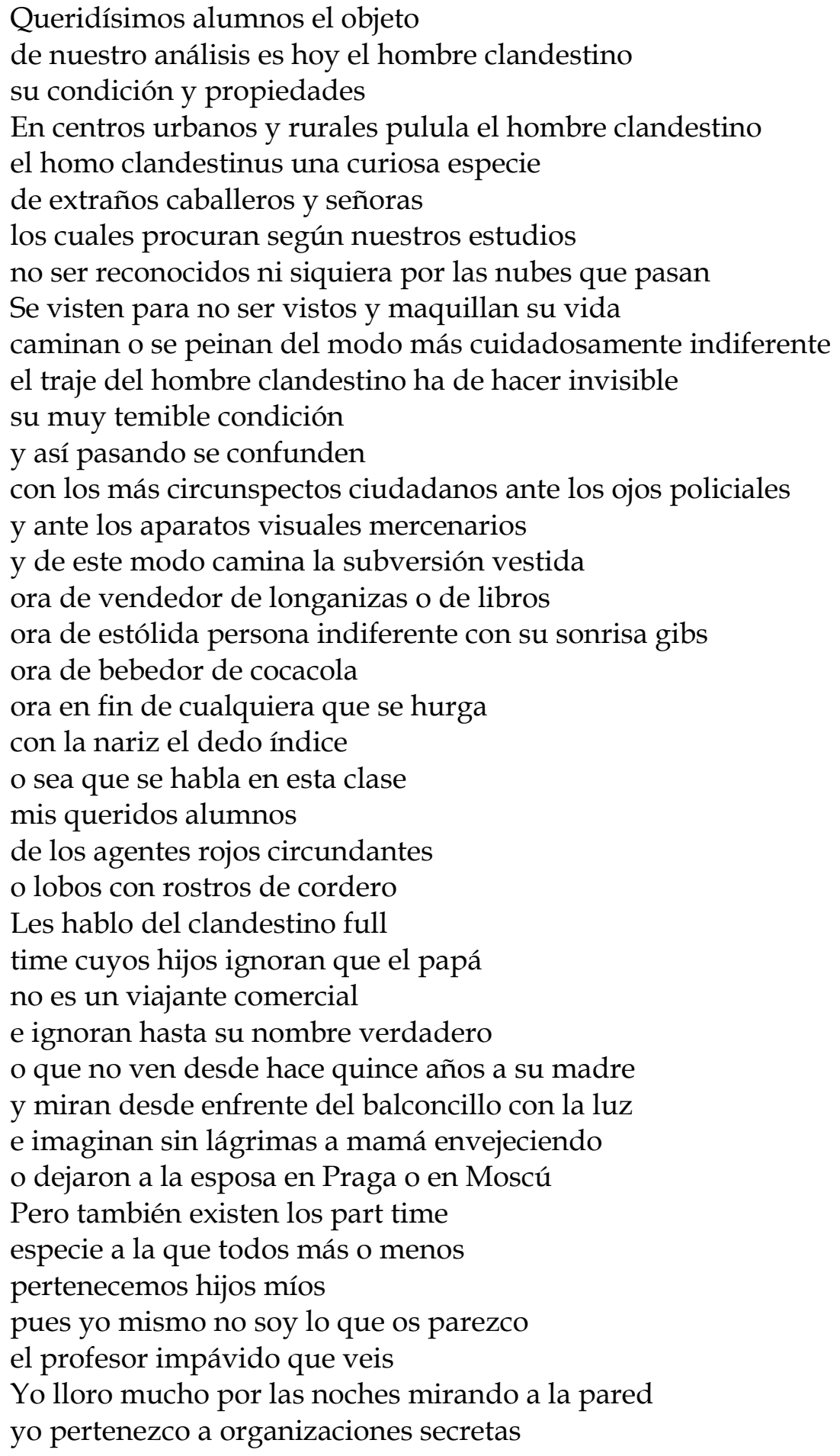




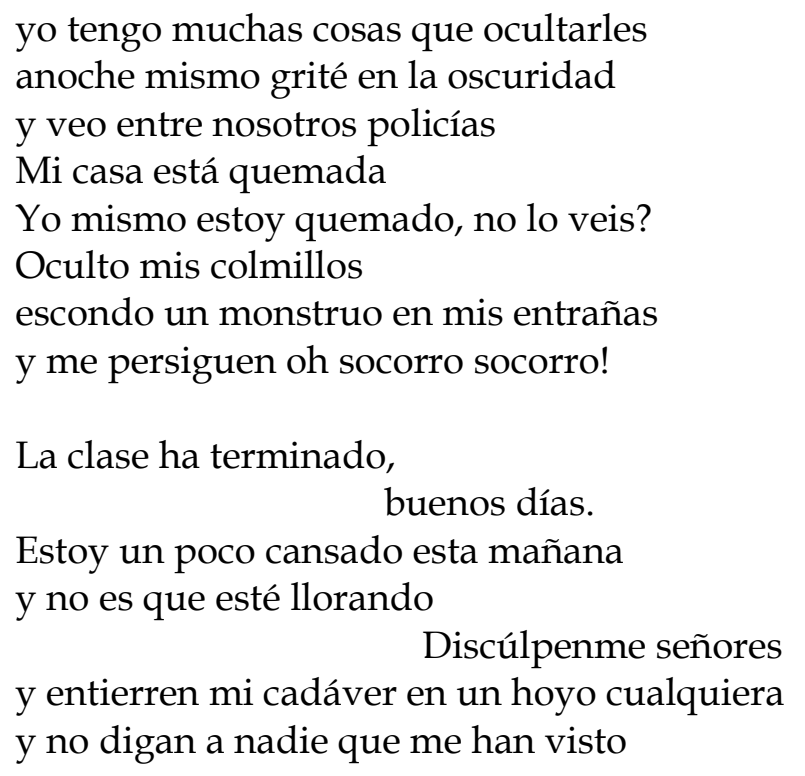

Ya el siguiente libro poético, último hasta la fecha, que publica Alfonso Sastre será su obra reunida, Obra lírica y doméstica. Poemas Completos. Lo primero que destaca del ejemplar es el enfoque histórico que ha guiado su composición final frente a la publicación fragmentaria de sus ediciones, facilitando así su panorámica en el tiempo. Obra lírica y doméstica comienza por el volumen El español al alcance de todos, el que recoge sus poemas más antiguos, seguido de T.B.O., La balada de Carabanchel y Vida del hombre invisible, respectivamente, respetando en lo posible el orden cronológico de escritura de los textos, mediante una disposición original y bien calculada de sus distintos libros.

Una novedad importante de Obra lírica y doméstica reside en la incorporación del inédito Residuos urbanos, formado por ocho cuadernos que completan y redondean su obra poética con nuevos poemas que oscilan entre los años cuarenta y la actualidad misma. El ejemplar se compone en gran parte por lo que Sastre denomina "residuos" de algunas de sus colecciones anteriores, es decir, textos que no llegaron a ver la luz en sus respectivas colecciones, rescatados expresamente para la edición y que complementan a su previo, 
como en los casos de "Las baladas ingenuas" (con textos de los años cuarenta), “Estética del cristianismo 2", (subtitulado "Tarde en la taberna" que continúa la línea general de sus "brindis" de comienzos de los años cincuenta); e, igualmente, su cuaderno "Drama sin apuntador", que vuelve de nuevo sobre variaciones líricas en torno al mundo del teatro y la representación. Por otro lado, hacen su aparición en Residuos urbanos sus "Seis sonetos para amigos", colección que subraya su dominio del metro clásico; y el cuaderno “Estética del cristianismo", donde desarrolla algunas de sus primeras preocupaciones sociales desde la óptica del pensamiento religioso ya expuestas con anterioridad. En todo caso, los textos de "Estética del cristianismo", además de ofrecer información sobre algunos aspectos importantes de su universo ideológico y cómo se formaron, como su concepto de pobreza, de igualdad, o de justicia (muy definidos ya a finales de los años cuarenta), ${ }^{25}$ se sitúan también en el centro mismo de su evolución hacia el realismo literario de signo crítico; por ejemplo, en el poema "Para no caer en el aburrimiento" (una de las obsesiones personales del escritor y donde se aprecia nítidamente la lectura de Charles Baudelaire) encontramos ya una voluntad de intervención y de transformación de la realidad, pero en un ángulo todavía netamente cotidiano (sin intervención en la vida política), planteado desde la soledad del individuo, donde el ejercicio mismo de la escritura se plantea como una intensificación de la vida:

Si os habéis quedado en casa esta tarde, doloridos, aquejados de sufrimientos pequeños, de dolor de cabeza, de resfriado; si os habéis quedado en casa esta tarde, no caigáis en el aburrimiento.

\footnotetext{
25 "Yo sufría mucho la falta de libertad de expresión, era uno de mis sufrimientos más fuertes en el orden social. Pero, sin embargo, no me preocupaba eso tanto como la injusticia. Cuando se hablaba de una sociedad comunista y se decía que allí no había libertades, no era una cosa que a mí me inquietara tanto como, si había una distribución de la riqueza". Francisco Caudet, Crónica de una marginación, op. cit., p. 41.
} 
No hay tristeza en el mundo, no hay melancolía que no desaparezca en la lectura de un buen libro. Si fumáis, el tabaco os servirá de mucho, pero dadle la importancia que tiene el placer de liarlo. En la segunda hora el libro será viejo y el poeta, si es bueno, amigo.

Entonces sacaréis el paquete de cartas que a lo largo de vuestra vida os han escrito.

En ellas hallaréis viejos saludos, viejos nombres, viajas caligrafías. Aprended ese gozo de releer papeles deslucidos.

Mas que no todo sea leer y recordar, sino escribid cartas, retratos de personas, historias sin conclusión ni objeto y sonetos galantes a nadie de este mundo; y pintad los absurdos dibujos que os salgan buenamente, caricaturas, sueños, paisajes, hombrecillos extraños, caras de loca, signos, en fin, con que fijas un poco el tiempo que se escapa.

A as ocho, cuando el crepúsculo vaya oscureciendo la ciudad, La luz eléctrica será un nuevo motivo de satisfacción.

No es poca cosa el milagro de una roja bombilla.

En la llama del gas os hacéis un café que tomaréis con calma. Si os duele la cabeza no os olvidéis del rito de una aspirina diluida en un vaso de agua porque todo remedio para ser eficaz ha de ser revestido de una especial liturgia.

Entonces, que la radio os traiga su mensaje: Chopin, Gershwin, Bing Crosby.

Es divertido por ejemplo manipular una radio

-la noche aún recién venidapara hallar emisoras lejanas; especialmente la de un pueblo extranjero que acaso ni siquiera tenga radio donde vive una bella muchacha que un día conocisteis.

Ya tenéis completado un programa de placeres sencillos para evitar esa caída en el pecado mortal que es el aburrimiento. ${ }^{26}$

${ }^{26}$ Alfonso Sastre, Obra lírica y doméstica. Poemas completos, Hiru, Hondarribia, 2004, pp. 416-417. 
Completan el ejemplar tres colecciones inéditas más. Por un lado, se encuentra el cuaderno "Versiones para leer en voz alta". Alfonso Sastre ofrece ahí una muestra significativa de su faceta como traductor (muy desarrollada también en su teatro), en este caso, atendiendo a textos de poetas románticos clásicos. Según explica en el prefacio, los poemas están pensados expresamente para ser recitados por un actor, ángulo en el que pueden apreciarse inflexiones dramáticas o escénicas de distinto signo. Entre ellos, se cuentan el "Poema de un viejo marino" de Samuel Taylor Coleridge; "El cuervo", "Ulalume” y "El dorado" de Edgar Allan Poe (los tres en versión libre); “Los barberos” de Julian Tuwim, sobre una variación de Ilhya Eremburg y "Esperando a los bárbaros" de Konstantino Kavafis sobre una versión italiana de los años sesenta. Por otro lado, aparecen las colecciones "Los tiempos difíciles" y "El alma en pena”, dos conjuntos que agrupan textos de los años sesenta y setenta, con otros plenamente actuales (1960-2000 y 1968-2004, respectivamente). Se trata de piezas intimistas donde la superposición de contenidos variados de tipo político (homenajes a Cuba, a Julián Grimau, al Frente Polisario, a la guerrilla salvadoreña o a la más reciente resistencia iraquí en Bagdad) alcanza verdaderas cotas de acierto y profundidad en el contraste con sus preocupaciones más humanas o éticas. Sastre dibuja un movimiento desde la circunstancia histórica excepcional, hasta lo más cotidiano y cercano de su vida, dando forma así a una extraordinaria capacidad de abstracción crítica de la realidad, lo que constituye, sin duda, una de las constantes poéticas clásicas y más logradas del autor. 


\section{[3. Conclusiones (breves apuntes para una poética)]}

Como ha podido observarse, la poesía de Alfonso Sastre se desenvuelve entre horquillas temporales muy amplias que reflejan, por lo tanto, estéticas muy variadas entre sí. Esa disposición desencajada y, en apariencia, aleatoria de sus distintos conjuntos de poemas, genera una lectura transversal y diacrónica que singulariza su universo lírico y lo define; todas sus publicaciones subrayan, enfáticamente, ese carácter discontinuo, lo que constituye una de sus características primeras y la más significativa. Se trata de una poesía que, analizada desde sus ediciones, se encuentra asociada al proceso histórico que transcurre desde la caída del régimen del general Franco hasta la llegada de la democracia parlamentaria en España. Con la excepción del periodo comprendido entre 1948 y 1951, sin duda, su momento, poéticamente, más fértil da comienzo en torno a 1974, coincidiendo con su encarcelación en la prisión de Carabanchel; desde entonces, no solo escribe muy intensamente poesía hasta el año 1980, aproximadamente, sino que (poco aficionado a la reescritura) se decide entonces, además, a hacer públicos sus inéditos. Entre los componentes de mayor relieve de su producción, se cuenta el uso de las técnicas teatrales (construcción de personajes, escenografías, efectos de situación), que declinan su poesía bien hacia ángulos dramáticos o cómicos, flexibilizando y amortiguando la expresión del yo lírico más subjetivo; en ese sentido, muestra notables aproximaciones tanto a la lírica popular, como a los registros clásicos, que utiliza de forma indistinta y regular; y destaca, especialmente, su notoria afinidad con la literatura romántica del XIX y el modernismo. Su verso presenta una absoluta permeabilidad a los acontecimientos que lo rodean, preservando su dimensión actual a través de un acercamiento dialéctico a las evidencias del mundo. Toda su poesía, incluso la más antigua, muestra una decidida 
inclinación hacia el realismo, cuyos mecanismos, procedimientos y texturas se definen y se consolidan (llegando a ser uno de sus teóricos más importantes) con la adopción de un compromiso humano con su tiempo, en lo que es una de las más significativas y originales adaptaciones del arte socialista a nuestra literatura contemporánea. Un poeta, a la vez, destimitificador y humano, revolucionario y melancólico, en cuyo verso resuena lo más íntimo y más personal que una voz poética pueda ofrecer a su lector: la voz de todos.

\section{Apéndice I. Organización histórica de las ediciones poéticas de AS.}

PUBLICACIONES POÉTICAS

-hasta 2004-

La Balada de Carabanchel y otros poemas celulares

(Ruedo Ibérico. París, 1976)

[Diciembre 1974 a Enero 1975]

"La Balada de Carabanchel"

"Otros poemas celulares"

El evangelio de Drácula

(Camp del 1'Arpa. Barcelona, 1976)

[Mayo 1975]

El español al alcance de todos

(Sensemayá. Madrid, 1978)

“Las baladas ingenuas" [1942 - 1948]

"Tarde en la taberna" [1951]

"Drama sin apuntador" [1948 - 1969]

"En algunos momentos" [1946 - 1971]

“Arrojado en el mundo" [1948 - 1960]

"Por encima de todo" [1960 - 1968]

“El español al alcance de todos" [1965]

"Poema penúltimo" [1960]
OBRA LÍRICA Y DOMÉSTICA. POEMAS

COMPLETOS, 2004

(Hiru. Hondarribia)

-El español al alcance de todos

[1942 - 1971]

-T.B.O.

[1963 - 1975]

-La Balada de Carabanchel y otros poemas celulares [1974 - 1975]

-Vida del hombre invisible contada por él mismo [1980] 
T.B.O.

(Zero Zyx. Madrid, 1978)

"Cuadernillos de anónimos" [ i? - 1974]

"Andar por casa" [1949 - 1975]

“Te veo Viet Nam" [1973 - 1975]

Vida del hombre invisible contada por él mismo.

(Endimión. Madrid, 1994)

[Octubre 1980]

El evangelio de Drácula

(Hiru. Hondarribia, 1997. reedición)

*Entre paréntesis y subrayados en negrita figuran editoriales, ciudades y años de publicación de los libros. Las referencias situadas entre corchetes indican la fecha de composición del ejemplar, o bien, de sus cuadernos y colecciones, en el caso de recopilaciones poéticas.

\section{[5 Apéndice II: Cronología completa}

AÑO

1942

¿1943?

¿1944?

1945

1946

1947

1948

"Otoño"

"Perdida infancia"

POEMA

"Dos poetas"

"Muerte"

"Poema 1" - "Poema 2"

"Primavera de 1946"

"Poema disonante"

"Las brujas" [febrero]

"Soneto adjetivo. Autorretrato de 1946"

"Despedida acróstica a Francisco" (i?)

"Broma para Carmen Geyer" [10 de julio]

"Pie para una foto en Alicante"

"Retrato de José María Palacio"

"Sobre Alfonso Paso"

"Los ahorcados" [mayo]

"Manifiesto de un teatro de vanguardia"

"Para Agustina Chavarri" [enero]

"Soneto para Enrica Pereno" [febrero]

"A modo de poeta" [marzo]

\section{COLECCIÓN}

Las baladas ingenuas

Las baladas ingenuas $\mathbf{R}$

Las baladas ingenuas

Las baladas ingenuas

Las baladas ingenuas $\mathbf{R}$

Las baladas ingenuas

Las baladas ingenuas

Las baladas ingenuas $\mathbf{R}$

En algunos momentos

En algunos momentos

Seis sonetos

Seis sonetos

Seis sonetos

Seis sonetos

Las baladas ingenuas $\mathbf{R}$

Drama sin apuntador $\mathbf{R}$

Seis sonetos

Seis sonetos

Las baladas ingenuas

\section{LIBRO}

EAT (1978)

OLD (2004)

EAT (1978)

EAT (1978)

OLD (2004)

EAT (1978)

EAT (1978)

OLD (2004)

EAT (1978)

EAT (1978)

OLD (2004)

OLD (2004)

OLD (2004)

OLD (2004)

OLD (2004)

OLD (2004)

OLD (2004)

OLD (2004)

EAT (1978) 
"Himno para estudiantes en primavera" [marzo]

"Poema para pedir auxilio en una fiesta"

"Final de un cuaderno"

"Algo como un llanto suave"

"A las seis de la tarde"

"Primer poema" (i?)

"Consigna para un muchacho" [marzo]

"Poema para un día de lluvia" [marzo]

"Bienaventurados los pobres" (i?)

"Para no caer en el aburrimiento" (i?)

"Poema para despedir a unas muchachas"

(i?)

"Para un amigo enamorado de la misma mujer"

"Fin del cuaderno" [marzo]

"Cuento de miedo para una actriz"

[septiembre]

"Tragedia en tres actos" [Otoño]

"Mensaje a un joven actor" [Otoño]

"Desdémona (un cuento)" [Otoño]

"Elegía a Monsieur Verdoux" (i?)

"Ignacio de Aldecoa" [Otoño]

"Para Carlos José Costas" [noviembre]

"Calle de la infancia (Ríos Rosas)"

1949

"Primer amor" [enero]

"Un día" [mayo]

"A Carmiña Martín Gaite, enferma"

1950

1951

1952

"Asfalto y jungla"

"Brindis de la perdida aventura" [marzo]

"Brindis de los niños que fuimos" [marzo]

"Brindis del exorcismo" [marzo]

"Brindis de la continuación" [marzo]

"Brindis de la copa de coñac" [6 de marzo]

"Primer brindis" [marzo]

"Brindis de la oración" [marzo]

"Mallorca" [agosto]

"Oda a Groucho Marx"

"Declaración de amor" [29 diciembre]

"Rastro de la mañana" [3 noviembre]

"Bar Casablanca" [28 enero]

"Confidencial" [febrero]

"Hijo mío" [13 abril]

"Andrómeda" [18 agosto]

"Cuento raíces" (i?)

"Subproletariado" ( $i ?)$

"Esperando a Godot" (i?)
Las baladas ingenuas

Las baladas ingenuas

Las baladas ingenuas

Las baladas ingenuas $R$

Las baladas ingenuas $R$

Estética del Xtianismo I

Estética del Xtianismo I

Estética del Xtianismo I

Estética del Xtianismo I

Estética del Xtianismo I

Estética del Xtianismo I

Estética del Xtianismo I

Estética del Xtianismo I

Drama sin apuntador

Drama sin apuntador

Drama sin apuntador

Drama sin apuntador

Drama sin apuntador

En algunos momentos

En algunos momentos

Arrojado en el mundo

En algunos momentos

Arrojado en el mundo

Andar por casa

Arrojado a la vida

Tarde en la taberna

Tarde en la taberna

Tarde en la taberna

Tarde en la taberna

Tarde en la taberna

Estética del Xtianismo II

Estética del Xtianismo II

En algunos momentos

Drama sin apuntador

En algunos momentos

Arrojado en el mundo

Arrojado en el mundo

Arrojado en el mundo

Arrojado en el mundo

Arrojado en el mundo

Arrojado en el mundo

Arrojado en el mundo

Arrojado en el mundo
EAT (1978)

EAT (1978)

EAT (1978)

OLD (2004)

OLD (2004)

OLD (2004)

OLD (2004)

OLD (2004)

OLD (2004)

OLD (2004)

OLD (2004)

OLD (2004)

OLD (2004)

EAT (1978)

EAT (1978)

EAT (1978)

EAT (1978)

EAT (1978)

EAT (1978)

EAT (1978)

EAT (1978)

EAT (1978)

EAT (1978)

TBO (1978)

EAT (1978)

EAT (1978)

EAT (1978)

EAT (1978)

EAT (1978)

EAT (1978)

OLD (2004)

OLD (2004)

EAT (1978)

EAT (1978)

EAT (1978)

EAT (1978)

EAT (1978)

EAT (1978)

EAT (1978)

EAT (1978)

EAT (1978)

EAT (1978)

EAT (1978) 
"Soneto de un triste en diciembre"

[diciembre]

1960 "Alguna soledad a modo de dedicatoria para nadie"

"Poema cer" [22 julio]

"Estreno" [agosto]

"Esta vida es la mía" (¿?)

"Unidad" ( $i ?)$

"Cristiano" ( $i ?)$

"Condiciones" (i?)

"Negro" [agosto]

¿? "Viva Fidel Castro"

"Eichman"

"Cruzada" (i?)

"Yo" (i?)

"Censura" (i?)

"Discurso del método" (¿?)

"Manifiesto" [agosto]

"Carta a Aldecoa" [2 agosto]

"El cuervo" [16 agosto]

"Muy importante" [ 21 agosto]

"Del suicidio" (¿?)

"Carta a mi padre"

"Hablo de Ferlosio"

"Hombre de Madrid" [agosto]

"Dedicarme a lo mío" (i?)

"Petición de socorro" (i?)

"Nueve versos sobre coacciones" [23 agosto]

"Protesta y firma" [5 septiembre]

1961 "5 de diciembre"

1963 Catorce Sonetos Einauditos [enero-febrero] "Soneto XV (Muerte de Julián Grimau)"

1964 "De Juan, hijo del poeta"

"Porque Eva le escribió" [Verano]

1965 "Réquiem por una actriz" [6-7 enero]

"El español al alcance de todos" [3 mayo]

1966 "Esperando a los bárbaros" de Constantino Kavafis. Versión en castellano [agosto]

"Ejecución del maleante" [3 diciembre]

1967 "Decimos paz" [febrero]

"Soneto a un falangista" [4 mayo]

"Testamento" [15-16 noviembre]

1968 "Comentario al robo de diez sonetos por la policía" [febrero]

"Nada de llantos" [abril]

"Vietnam, Vietnam"

"Ho Chi Minh (homenaje)"

"Discurso del método (balada)"

"Baladilla de la guerra de África" [mayo]

"Te veo, Vietnam"
En algunos momentos

EAT (1978)

(Prólogo)
(Prólogo)

EAT (1978)

Drama sin apuntador

Por encima de todo

Por encima de todo

Por encima de todo

Por encima de todo

Por encima de todo

Por encima de todo

Por encima de todo

Por encima de todo

Por encima de todo

Por encima de todo

Por encima de todo

Por encima de todo

En algunos momentos

Arrojado en el mundo

Arrojado en el mundo

Arrojado en el mundo

Arrojado en el mundo

Arrojado en el mundo

Poema penúltimo

Tiempos difíciles

Tiempos difíciles

Tiempos difíciles

Por encima de todo

En algunos momentos

Cuadernillo de anónimos

Tiempos difíciles

Andar por casa

Andar por casa

Drama sin apuntador

El español al alcance...

Versiones para leer...

Arrojado en el mundo

Por encima de todo

Andar por casa

Arrojado en el mundo

Tiempos difíciles

Por encima de todo

Por encima de todo

Por encima de todo

Cuadernillos de anónimos

Cuadernillos de anónimos

Te veo Vietnam
EAT (1978)

EAT (1978)

EAT (1978)

EAT (1978)

EAT (1978)

EAT (1978)

EAT (1978)

EAT (1978)

EAT (1978)

EAT (1978)

EAT (1978)

EAT (1978)

EAT (1978)

EAT (1978)

EAT (1978)

EAT (1978)

EAT (1978)

EAT (1978)

EAT (1978)

EAT (1978)

EAT (1978)

OLD (2004)

OLD (2004)

OLD (2004)

EAT (1978)

EAT (1978)

TBO (1978)

OLD (2004)

TBO (1978)

TBO (1978)

EAT (1978)

EAT (1978)

OLD (2004)

EAT (1978)

EAT (1978)

EAT (1978)

OLD (2004)

EAT (1978)

EAT (1978)

EAT (1978)

TBO (1978)

TBO (1978)

TBO (1978)
TBO (1978) 
"Para su madre en el 43 cumpleaños del poeta desde un refugio de la sierra madrileña" [20 febrero]

"Porque la yaya y Evita tuvieron un problema en el parque de la calle de la Virgen de Nuria" (¿?)

"Esta mañana" [21 marzo]

"Réquiem por una actriz asesinada" [10 agosto]

"Postal a mi madre" [12 noviembre]

"A su hijo Pablo porque sacó un notable en inglés" [septiembre]

1970 "Elegía en la muerte del Tabernero Juanito Carretón" [20-22 Junio]

TBO (1978)

"Salamanca" [agosto]

"El poeta habla a propósito de las declaraciones oficiales contra la violencia" [diciembre]

TBO (1978)

Arrojado en el mundo

EAT (1978)

Drama sin apuntador

EAT (1978)

En algunos momentos

EAT (1978)

Andar por casa

TBO (1978)

En algunos momentos

EAT (1978)

Arrojado en el mundo

EAT (1978)

"Estado de excepción en seguidillas"

[diciembre]

"Por la cuadernavía" [24 diciembre]

1971 "Balada para incorporar a un drama" [enero]

"Pablo, mi hijo, en Coria del Río" [4 enero]

"Han borrado mi nombre" [13 abril]

"Broma al terminar en Estocolmo" [6 agosto]

"Rotura de picassos en Madrid por los héroes de

Cristo Rey" [noviembre]

Cuadernillos de anónimos

TBO (1978)

Cuadernillos de anónimos

TBO (1978)

Cuadernillos de anónimos

TBO (1978)

Drama sin apuntador $\mathbf{R}$

OLD (2004)

En algunos momentos

EAT (1978)

Arrojado en el mundo

EAT (1978)

Andar por casa

TBO (1978)

Cuadernillos de anónimos

TBO (1978)

1972 "De cómo la inteligentsia madrileña se conmovió viendo un film de Rafael Gil" [marzo]

Cuadernillos de anónimos

TBO (1978)

“Que Nicolás Guillén le dio un poema de Nancy Morejón" [23 mayo]

"Que su hijo Pablo se fue a Inglaterra" [13 julio]

"Seguidillas para Pablo a Inglaterra" [20 julio]

“Noticias de la familia a muchacho que está en Inglaterra" [9 agosto]

"Redondillas para Pablo sobre algunos problemas de munición de boca en Inglaterra" [28 julio]

"Soneto escrito por este poeta" [octubre]

"Telegrama a un amigo chileno" [15 septiembre]

"Homenaje del poeta maldito Ildefonsus del

Sarto a su amigo Carolo" (¿?)

"De que las cosas han de tener su final"

"Acróstico en el que un lobo solitario habla del otro lobo o gran licántropo politicus-

"Aleluyas del 73"

1974 "Guerrilleros artistas" [febrero]

"Un soneto aproximadamente"

"Al retrete de mi celda"

“De que su niña estaba triste" [15 marzo]

Andar por casa

Andar por casa

Andar por casa

TBO (1978)

TBO (1978)

TBO (1978)

Andar por casa

Andar por casa

Andar por casa

Cuadernillos de anónimos

Andar por casa

Andar por casa

Andar por casa

Te veo Vietnam

Cuadernillos de anónimos

Cuadernillos de anónimos

Cuadernillos de anónimos

Andar por casa
TBO (1978)

TBO (1978)

TBO (1978)

TBO (1978)

TBO (1978)

TBO (1978)

TBO (1978)

TBO (1978)

TBO (1978)

TBO (1978)

TBO (1978)

TBO (1978) 
"Seguidillas de Pepe" [marzo]

"Pies para doce fotografías" [marzo]

"Seguidillas carceleras a Evita Sastre"

"El poeta cuenta a su madre..." [4

noviembre]

"Carta a mi hijo Juan en octubre" [24 octubre]

"Soneto a la yaya" [2 noviembre]

"A Pablo en Roma (Acróstico)"

[15-18 noviembre]

"En la noche de un 20 de diciembre, poeta inopinadamente empezó esta Balada"

[20 diciembre]

"Una noticia tonta" [21 diciembre]

"Nota a Santiago Carrillo" [25 diciembre]

"El poeta reflexiona estupefacto"

[25 diciembre]

"Lectura de un recorte y nota para un asesino" (¿?)

"Nada nuevo" [27 diciembre]

"Comunicación 20 minutos" [28 diciembre]

“¿Por qué te presentaste?" [28-29 diciembre]

"TV en la taberna: horror y nuevas aventuras" [30 diciembre]

"El poeta se acuerda de los demás y acepta su cuota de dolor" [30 diciembre] [marzo]

"Despertar en celda de castigo" [8 enero]

"A los compañeros conocidos y desconocidos" [10 enero]

"Octavilla urgente por mi compañera"

[10-11 enero]

"Esta mañana el poeta ha escrito versos para que un preso de 16 años escriba a su madre" (i?)

"El pequeño testamento" [11 enero]

"Salud" [11 enero]

"Final de la Balada" [12 enero]

"Aleluyas carcelarias en el año nuevo"

[enero]

"Homenaje a Machado" [21marzo]

"Este gitano" [abril]

"Seguidillas para una niña"

"1 de mayo en la prisión" [2 mayo]

"Una flor sobre mis libros" [3 mayo]
Andar por casa

Andar por casa

Andar por casa

Andar por casa

Otros poemas celulares

Otros poemas celulares

Otros poemas celulares

Balada De Carabanchel

La Balada De Carabanchel

La Balada De Carabanchel

La Balada De Carabanchel

La Balada De Carabanchel

La Balada De Carabanchel

La Balada De Carabanchel

La Balada De Carabanchel

La Balada De Carabanchel

La Balada De Carabanchel

La Balada De Carabanchel

La Balada De Carabanchel

La Balada De Carabanchel

La Balada De Carabanchel

TBO (1978)

TBO (1978)

TBO (1978)

ТВО (1978)

BC (1976)

$B C$ (1976)

BC (1976)

BC (1976)

BC (1976)

$B C$ (1976)

BC (1976)

$B C$ (1976)

$B C$ (1976)

$B C$ (1976)

$B C$ (1976)

$B C$ (1976)

BC (1976)

BC (1976)

$B C$ (1976)

$B C$ (1976)

BC (1976)

La Balada De Carabanchel

BC (1976)

BC (1976)

La Balada De Carabanchel

BC (1976)

La Balada De Carabanchel

BC (1976)

$B C$ (1976)

$B C$ (1976)

BC (1976)

Otros poemas celulares

$B C$ (1976)

$B C$ (1976)

$B C$ (1976)

$B C$ (1976)

$B C$ (1976) 
"Filosofía de la praxis" [5 mayo]

"El alejandrino al servicio del pueblo"

[13 mayo]

"Noche de tempestad" [14 mayo]

"Castillo de Vampiro"

"Gastronomía, Teatro, Religión"

"Misericordia y rebelión"

"Intermedio con literatura"

"Ejercicios espirituales"

"Sus apóstoles"

"Novísimo testamento"

"Los invitados"

"Continuación del novísimo testamento"

“¡Oh Sor María, oh Sor María!"

"Su ejemplo muerte y resurrección"

"El pálido anfitrión"

"La eterna melancolía del vampiro"

"Retírense a dormir"

"Página de sucesos"

"Berceuse para un vampiro"

"El autor se despide de la mano del diablo

haciendo un guiño a la crítica literaria"

[15 mayo]

"Mariluz (Homenaje)" [24 mayo]

"Aleluyas del 75" [mayo]

"Se han llevado a Tupa" [junio]

1978 "Pequeña elegía para un hombre delgado"

1979 "El Cuervo" de Edgar Allan Poe.

Versión en castellano [20 septiembre]

“Ululame" de Edgar Allan Poe.

Versión en castellano (i?)

"El dorado" de Edgar Allan Poe.

Versión en castellano (i?)

1980 "Desde estas altas torres" [octubre]

"Niña de comisario"

"El poeta oye que alguien sube en el ascensor"

"Checa de Recoletos"

"Salir"

"París y carros de combate"

"Volver"

"Asturias en soledad"
Otros poemas celulares

Otros poemas celulares

BC (1976)

BC (1976)

EED (1976)

EED (1976)

$\bullet$

$\bullet$

$\bullet$

$\bullet$

-

-

$\bullet$

$\bullet$

-
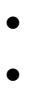

-

$\bullet$

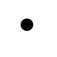

$\bullet$

$\bullet$

$\bullet$

•

Otros poemas celulares Te veo Vietnam

Otros poemas celulares

El alma en pena

Versiones para leer en voz alta

Versiones para leer en voz alta

EED (1976)

EED (1976)

EED (1976)

EED (1976)

EED (1976)

EED (1976)

EED (1976)

EED (1976)

EED (1976)

EED (1976)

EED (1976)

EED (1976)

EED (1976)

EED (1976)

EED (1976)

EED (1976)

BC (1976)

TBO (1978)

BC (1976)

OLD (2004)

OLD (2004)

OLD (2004)

Versiones para leer en voz alta

OLD (2004)

VHI (1994)

VHI (1994)

VHI (1994)

VHI (1994)

VHI (1994)

VHI (1994)

VHI (1994)

VHI (1994) 
"Reunión de Partido"

"Yo no sabía que te llamabas Julián Grimau"

"Baeza"

"De si el poeta es comunista"

"Tiembla mi mano en esta asamblea contra la represión"

"Descensus ad inferos"

"Entierro de Justo López"

"Esperando la mano de nieve"

"Fuego"

"Es evidente que me siguen"

"Bululú"

"Tratado del hombre clandestino"

"Más fantasma que nunca"

"Burgos alma hilo"

"Tinto en tinta"

"El poeta invisible"

"Raro"

"Receta falible para curva perfecta"

"No sé si otro sueño"

"Antes o después acaba uno"

"Nuevas aventuras del hombre invisible"

"Diana"

"Novela policíaca"

"El filo de la navaja"

"Asalto a Miraflores por fuerzas de la Guardia Civil"

"Gusto y misterio de la clandestinidad"

"Es fácil por la noche fugarse de la cárcel"

"Otro sueño"

"He tenido que disparar no ha habido más remedio"

"Esposas"

"Registros domiciliarios"

"Aquí estamos seguros"

"Legalización del Partido Comunista"

"Segovia"

"Paseo de las delicias"

"Historieta"

"Arroz amargo"

"Spleen de Bordeaux"

"Pistola"

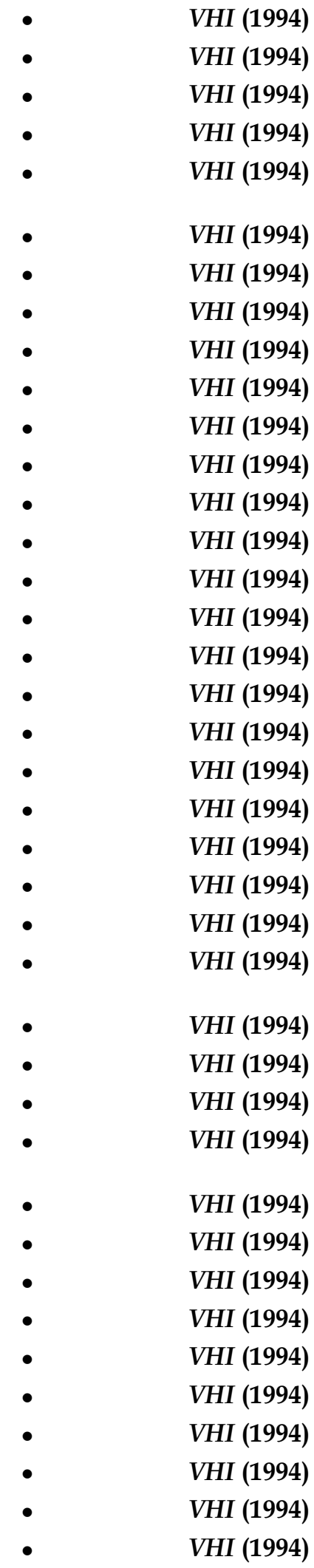




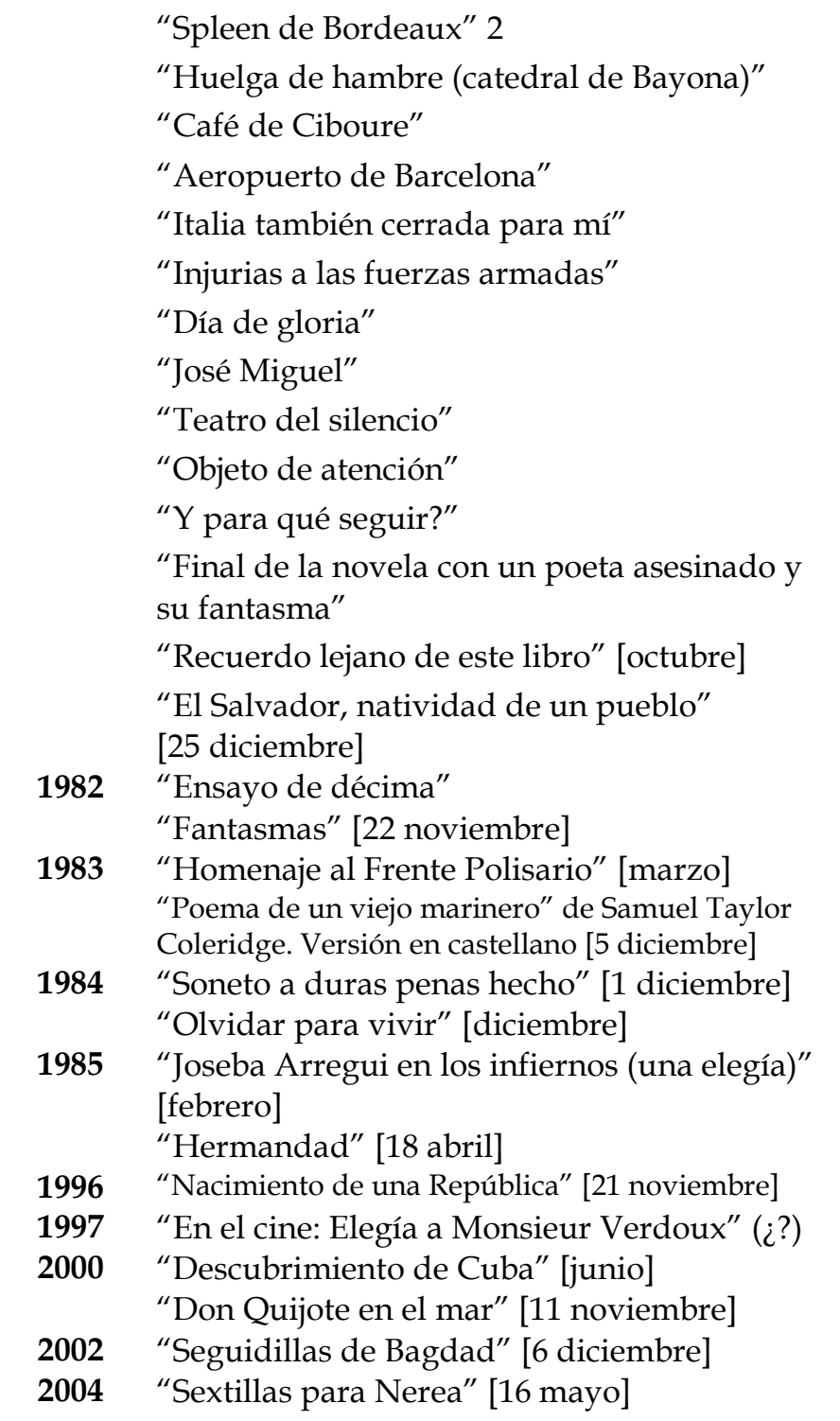

\begin{tabular}{|c|c|}
\hline - & VHI (1994) \\
\hline$\bullet$ & VHI (1994) \\
\hline - & VHI (1994) \\
\hline • & VHI (1994) \\
\hline • & VHI (1994) \\
\hline • & VHI (1994) \\
\hline$\bullet$ & VHI (1994) \\
\hline$\bullet$ & VHI (1994) \\
\hline - & VHI (1994) \\
\hline - & VHI (1994) \\
\hline - & VHI (1994) \\
\hline • & VHI (1994) \\
\hline$\bullet$ & VHI (1994) \\
\hline Tiempos difíciles & OLD (2004) \\
\hline El alma en pena & OLD (2004) \\
\hline El alma en pena & OLD (2004) \\
\hline Tiempos difíciles & OLD (2004) \\
\hline $\begin{array}{l}\text { ersiones para leer en voz } \\
\text { alta }\end{array}$ & OLD (2004) \\
\hline El alma en pena & OLD (2004) \\
\hline El alma en pena & OLD (2004) \\
\hline El alma en pena & OLD (2004) \\
\hline El alma en pena & OLD (2004) \\
\hline Tiempos difíciles & OLD (2004) \\
\hline Drama sin apuntador $\mathbf{R}$ & OLD (2004) \\
\hline Tiempos difíciles & OLD (2004) \\
\hline El alma en pena & OLD (2004) \\
\hline El alma en pena & OLD (2004) \\
\hline El alma en pena & OLD (2004) \\
\hline
\end{tabular}

\section{- CRITERIOS}

-Caja "AÑO" indica fecha genérica de composición del texto.

-Caja "POEMA" indica título de texto, su día y mes de composición (si es conocido).

-Caja "COLECCIÓN" indica el cuaderno o capítulo del ejemplar donde se integra el texto.

-Caja "LIBRO" indica ejemplar y año de su primera edición.

-Interrogante en la caja "AÑ" indica duda del autor sobre la fecha de composición del texto. -Interrogante en la caja "POEMA", aislado entre paréntesis y situado tras el título, indica falta de datos, duda o indicio razonable sobre su datación.

\section{-ABREVIATURAS:}

[1] BC: La Balada de Carabanchel y otros poemas celulares (1976)

[2] EED: El evangelio de Drácula (1976)

[3] EAT: El español al alcance de todos (1978) 
Cronología y apuntes sobre las ediciones poéticas de Alfonso Sastre

[4] VHI: Vida del hombre invisible contada por él mismo (1994)

[5] OLD : Obra lírica y doméstica. Poemas completos (2004)

[6] R: (Residuos) 